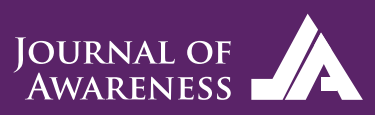

8
Journal of Awareness

Volume / Cilt: 6, Issue / Sayl:4, 2021, pp. 213-221

E-ISSN: 2149-6544

https://journals.gen.tr/joa

DOI: https://doi.org/10.26809/joa.6.4.03
Received / Geliș: 26.07.2021 Accepted / Kabul: 16.09.2021

\title{
Covid-19 araştırmalarında Türkiye kaynaklı yayınların sosyal ağ analizi ile incelenmesi
}

\author{
Examination of Turkey based publications in covid-19 \\ researches with social network analysis
}

\section{Özlem Ergüt ${ }^{1}$ (1) Esra Yurtsever ${ }^{2}$}

1 Dr. Öğr. Üyesi, Marmara Üniversitesi, İktisat Fakültesi, Ekonometri Bölümü, İstanbul, Türkiye, e-mail: ozlem.ergut@marmara.edu.tr

2 İstatistik Tezli YL Öğrencisi, Marmara Üniversitesi, Sosyal Bilimler Enstitüsü, İstatistik YL, İstanbul, Türkiye, e-mail: yurtseveresraa@gmail.com

Öz

Aralık 2019'da Çin Halk Cumhuriyeti'nin Hubei eyaleti Wuhan kentinde başlayan Covid-19, kısa bir zaman içinde tüm dünyaya yayılmış ve 11 Mart 2020 tarihinde Dünya Sağlık Örgütü (WHO) tarafından pandemi olarak ilan edilmiştir. Dünyanın her yerinden milyonlarca insanın enfekte olmasına ve yaşamını yitirmesine neden olan Covid-19, dünyada ve ülkemizde birçok alanda birçok çalışmaya konu olmuştur. Bu çalışmada, Türk araştırmacıların Covid-19 ile ilgili yapılan araştırmalara olan katkılarının incelenmesi amaçlanmaktadır. Çalışmada Web Of Science veri tabanı üzerinden Covid-19 ile bağlantılı terimler kullanılarak yapılan arama sonucunda iki yıllık süreç içerisinde gerçekleştirilen çalışmalar incelenmiştir. Elde edilen yayınlar; yıl bazındaki sıklık, yayın türü, yayınlandı̆̆ı dergi, yayın dili, yöntem, araştırmacıların çalışma alanları, kurumları ve ülkeleri yönünden analiz edilmiştir. Araştırmacıların özellikle hangi alanda en fazla sayıda çalışmaya imza attıkları da saptanmıştır. Aynı zamanda belirlenen alanda çalışan kişiler ve kurumlar arasındaki ağ yapısı

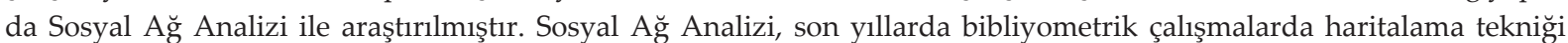
olarak sıklıkla kullanılan analizlerden biri haline gelmiştir. Sosyal Ağ Analizi'nin bu amaç doğrultusunda kullanılması araştırılan konuda öne çıkan üretken aktörlerin ve aralarındaki ilişkilerin ortaya çıkarılmasına olanak sağlamaktadır. Yapılan analiz sonucunda yazarlar arasında küçük gruplar arasında iş birliklerinin olduğu söylenebilmektedir. Kurumlar arasındaki ağ yapısı analiz edildiğinde ise kurumlar arası iş birliklerinin ön plana çıktığı, kurumların daha fazla köprü rolü oynadığı saptanmıştır. Yazarlar arasındaki iş birliğinin devam etmesi, pandemi sürecinde elde edilen bulguların paylaşılması ve bunların incelenmesi, gerekli düzenlemelerin yapılmasında kaynak teşkil etmesi açısından önemlidir. Çalışmada anahtar kelimeler ve özetler de incelenerek belirlenen alan üzerinde yoğunlaşılan ana konular, analiz teknikleri ile belirlenmiştir. Elde edilen bulguların mevcut durumu ortaya koyarak ilerleyen zamanlarda yayınlanacak çalışmalara birçok açıdan yol gösterici olacağı düşünülmektedir.

Anahtar kelimeler: Covid-19, Sosyal A $\breve{g}$ Analizi, Pandemi 


\begin{abstract}
The Covid-19 outbreak, which started in December 2019 in Wuhan, Hubei province of China, spread all over the world in a short time and was declared as a pandemic by the World Health Organization (WHO) on March 11, 2020. The Covid-19 outbreak, which caused millions of people to become infected and die from all over the world, has been the subject of many studies in many areas in the world and in our country. In this study, the aim is to examine the contributions of Turkish researchers to researches on Covid-19. In this study, the research carried out over a two-year period was examined as a result of a search using terms related to Covid-19 through the 'Web of Science' database. Publications obtained; year-based frequency, type of publication, published journal, purpose, method, study areas of the researchers, institutions and countries were analyzed. It was also determined in which field the researchers signed the most. At the same time, the network structure between people and institutions working in the specified field was searched by Social Network Analysis. Social Network Analysis has become one of the most frequently used analysis as a mapping technique in bibliometric studies in recent years. The use of social network analysis for this purpose allows to reveal the productive actors and their relationships that stand out in the subject being searched. As a result of the analysis, it can be said that there are collaborations between small groups among the authors. When the network structure between institutions is analyzed, it has been determined that the cooperation between the institutions comes to the fore and the institutions play a more bridging role. It is important to continue cooperation between authors, to share the findings obtained in the pandemic process, to study them and to provide resources for making the necessary arrangements. In the study, key words and abstracts were examined and the main topics and analysis techniques were determined. It is thought that the findings obtained will be a guide in many respects to the studies to be published in the future by revealing the current situation.
\end{abstract}

Keywords: Covid-19, Social Network Analysis, Pandemic

\section{GİRIŞ}

Bütün dünyayı etkisi altına alan Covid-19, 31 Aralık 2019 tarihinde Çin' de zatürre benzeri bir hastalığın duyurulması ile ilk kez gündeme gelmiştir (DSÖ, 2020). 11 Ocak 2020 tarihinde Çin'de gerçekleşen ilk ölüm ile hastalığın ölüm potansiyeline sahip olduğu anlaşılmıştır. Başlangıçta 2019-nCov olarak ifade edilen bu hastalık, daha sonra Covid-19 olarak adlandırılmıştır (Budak ve Korkmaz, 2020). Covid-19'un kişiden kişiye hızlıca bulaşması dünya çapında milyonlarca insanın etkilenmesine sebep olmuştur. 13 Ocak 2020 tarihinde ilk kez Tayland'da görülmesi ile birlikte dünya çapında yayılmaya başlamıştır. Türkiye' de ilk Covid-19 vakası ise 11 Mart 2020 tarihinde açıklanmıştır (Sağlık
Bakanlığı, 2020). Yine 11 Mart 2020 tarihinde Covid-19 DSÖ tarafından pandemi olarak ilan edilmiştir. Pandemi, bir hastalığın veya enfeksiyon etkeninin ülkelerde, kıtalarda, hatta tüm dünya gibi çok geniş bir alanda yayılım göstermesi olarak tanımlanmaktadır (Sağlık Bakanlığı, 2020). Covid-19'un hızlı yayılmaS1 ve insandan insana kolayca bulaşması vaka sayısı takibini önemli kılmış, ülkeler durumlarındaki değişmeyi incelemek amacıyla vaka sayılarını kayıt altına alarak takip etmeye başlamışlardır. Covid-19 vaka sayılarının ülkeler içindeki yoğunluklarını göstermek amacıyla 11 Haziran 2021 tarihine kadar kayıtlara geçen Covid-19 vaka sayılarına ait harita aşağıdaki Şekil 1 'de sunulmuştur.

Şekil 1. Dünyada Covid-19 Kaynaklı Güncel Vaka Sayıları (11 Haziran 2021)

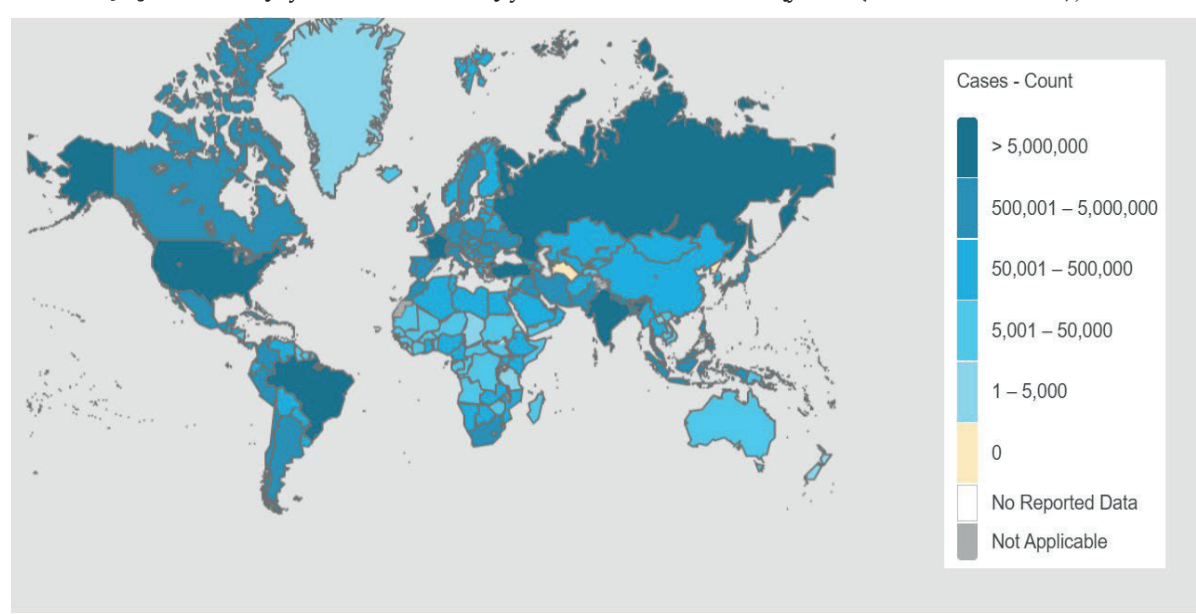

Kaynak: DSÖ, https://covid19.who.int/ 
Tüm dünyaya yayılan Covid-19 virüsü neredeyse yaşamın her alanında kısa ve uzun vadeli değişmelere neden olmuştur. Covid-19 virüsünün yayılmasını yavaşlatmak ve engellemek için ülkeler tarafından çeşitli politikalar, tedbirler ve önlemler devreye sokulmuştur. Bu politikalar sosyal ve ekonomik açıdan bireylerin günlük yaşamına etki etmiştir.

Dünya bazında gerçekleşen değişimler fiziksel sağlık, psikolojik sağlık, ekonomi, eğitim, istihdam, teknoloji, ulaşım ve olağan günlük yaşamın bir parçası olan her alanı etkilemiştir. Bu değişimler araştırmacılarında bu alanlarda birçok çalışma yapmasına neden olmuştur. Başta tıp olmak üzere, eczacılık, psikoloji, ekonomi, eğitim, teknoloji gibi birçok farklı alanda çalışmalara imza atılmıştır.

Covid-19 ile salgının daha fazla yayılmadan müdahale edilmesi açısından çeşitli önlemler almak adına pek çok alanda iş birliği önemli hale gelmiştir. Bu bağlamda Covid-19 ile ilgili çalışmaların incelenmesi ve ortak yazarlık ilişkilerinin belirlenerek iş birliği ağının arttırılması ilerleyen dönemlerde yapılacak çalışmalara kaynak teşkil edip, bilgi paylaşımının artmasıyla mevcut problemlere daha etkin çözümler bulunmasını kolaylaştıracak nihayetinde bilimsel çalışmaların gelişimini hızlandıracaktır.

Bu çalışmanın amacı, Covid-19 araştırmalarında Türkiye kaynaklı yayınları yayın yılı, yayın dili, yayınlandığı doküman türleri, yayın kaynakları, yayınlandığg ülkeler, yayınlandığı kurumlar ve yayınların araştırma alanları bazında inceleyerek; yayınların yazarlar arası, ülkeler arası ve kurumlar arası ağ yapısını ortaya koymaktır. Bununla birlikte bir diğer amaç, yayınlara ait özet ve anahtar kelimeler incelenerek yoğunlaşılan ana konuları belirlemektir. Bu amaç doğrultusunda bibliyometrik çalışmalarda haritalama tekniği olarak sıklıkla kullanılan analizlerden biri olan Sosyal Ağ Analizi (SAA)'nden yararlanılmıştır.

\section{BİBLIYYOMETRİ VE SOSYAL AĞ ANALİİ}

Bibliyometri, yayınlanmış dergi, kitap vb. bilimsel bilgi paylaşım araçlarının matematiksel ve istatistiksel tekniklerle incelenmesinde kullanılan bir yöntem olarak tanımlanabilir (Pritchard, 1969). Bibliyometri, farklı araştırma alanlarındaki yayınların belirlenen dönem içerisindeki özet bilgilerinin elde edilmesini sağlayarak, alanın gelişimi hakkında bilgi vermesi açısindan önemli bir yere sahiptir. Belirli bir dönemdeki yayınlar yazarlar, kurumlar ve terimler incelenip; li- teratüründe ön plana çıkan yayın ve yazarları belirlemek amacıyla atıf analizinden yararlanılabilmektedir. Anahtar kelimelerin ayrıntılı olarak incelenmesi ile çalışılan konuların yoğunluğu görülüp, eğilimler takip edilebilmekte ve alandaki anahtar kavramlar arasındaki ilişkiler belirlenebilmektedir.

Son yıllarda bibliyometri ile ilgili yapılan çalışmalarda araştırmacıların sosyal olguları ve sosyal yapıyı ilişkiler temelinde analiz etmelerine yardımcı olan SAA'dan yararlandığı sıklıkla görülmektedir. Bilimsel haritalama ya da bibliyometrik haritalama disiplinlerin, alanların, uzmanlıkların ve yayınların ya da yazarların birbirleriyle nasıl ilişkili olduğuna dair bir temsiliyet sağlamaktadır (Small, 1999). Bilimsel haritalama, araştırmacıların değerler ve yayınların çeşitli yönleri arasındaki ilişkileri kolayca anlamalarına yardımcı olmaktadır.

Sosyal A $\breve{g}$ Analizi yazarlar, kurumlar, departmanlar ve ülkeler arasındaki ilişkileri haritalandırarak ve analiz ederek ilişki ağlarının değerlendirilmesini sağlayan bir tekniktir (Racherla ve Hu, 2010). Geniş bir uygulama alanına sahip olan SAA, bireyler/nesneler arasındaki bağlantıları ortaya çıkarılabildiğinden, sosyal aktivitenin kapsamını ve etkisini belirleme ve ölçme fırsatı sağlamaktadır. SAA ile sosyal ağları inceleyerek karmaşık halde bulunan ilişkiler, daha sade ve anlaşılabilir hale getirilip, hem mikro düzeydeki ilişki kümelerini hem de tüm birimler arasındaki bağlantıları gösteren makro düzeydeki ağ yapısını ortaya çıkarmak ve elde edilen bulguları detaylı olarak yorumlamak mümkündür (Yıldırım ve Ergüt, 2014).

\section{VERI SETI}

Çalışma kapsamında, Web Of Science veri tabanı üzerinden 2020 ve 2021 y1llarına ait Covid-19 ile bağlantılı terimler kullanılarak yapılan arama sonucunda gerçekleştirilen çalışmalar incelenmiştir. Çalışma kapsamında oluşturulan veri seti 2021 Mayıs sonu itibariyle yayınlanmış çalışmalar ve erken erişime açılan yayınlardan oluşmaktadır. Elde edilen yayınların yıl bazındaki sıklık, yayın türü, yayın dili, yayınlandığı dergi, yöntem, araştırmacıların çalışma alanları, kurumları ve ülkelerine ait tanımsal istatistikleri öncelikle incelenmiş olup, sonraki aşamada yazarlar, kurumlar ve ülkeler arasındaki iş birliği SAA ile analiz edilmiştir. Verilerin analizinde VOSviewer programından yararlanılmıştır. 


\section{BULGULAR}

\subsection{Tanımsal İstatistikler}

Covid-19 araştırmalarında Türkiye kaynaklı yayınların yıllara göre dağılımı Tablo 1'de sunulmuştur.

Tablo1. Yayınların Yıllara Göre Dağılımı

\begin{tabular}{|l|l|}
\hline Yıl & Yayın Sayısı \\
\hline 2020 & 1845 \\
\hline 2021 & 844 \\
\hline
\end{tabular}

Çalışmanın yapıldı ̆̆ tarihte 2020 ve 2021 yıllarına ait toplam yayın sayısı 2689' dur.

Tablo 2'de yayınların ilk 5 sırada yer alan doküman türlerine göre dağılımları yer almaktadır.

Yayınların doküman türüne göre dağılımları incelendiğinde ilk sırada \%65'lik oranla makalelerin yer aldığı görülmektedir. Bunu derleme ve mektuplar izlemektedir.

En fazla makale yayınlanan 15 dergi Tablo 3'te verilmiştir. Tablo incelendiğinde en çok yayın sayısının Dermatologic Therapy Dergisi'ne ait olduğu, bu dergiyi ise Journal of Medical Virology Dergisi'nin takip ettiği görülmektedir. Makalelerin yayınlandıkları dergilere göre dağılımı incelendiğinde çalışmaların özelikle tıp alanında yoğunlaştığı görülmektedir.

Tablo 2. Yayınların Doküman Türüne Göre Dağılımları

\begin{tabular}{|l|l|}
\hline Doküman Türü & Yayın Sayısı \\
\hline Makale (Article) & 1773 \\
\hline Erken Erişimli Yayın (Early Access) & 420 \\
\hline Derleme (Review) & 407 \\
\hline Mektup (Letter) & 313 \\
\hline Editöryel Yayın (Editorial Material) & 166 \\
\hline
\end{tabular}

Tablo 3. En Fazla Makale Yayınlayan Dergiler

\begin{tabular}{|l|l|}
\hline Yayınlanan Dergi & Yayın Sayısı \\
\hline Dermatologic Therapy & 59 \\
\hline Journal of Medical Virology & 45 \\
\hline Bezmialem Science & 44 \\
\hline International Journal of Clinical Practice & 44 \\
\hline Turkish Journal of Medical Sciences & 43 \\
\hline Perspectives in Psychiatric Care & 34 \\
\hline Gazi Medical Journal & 29 \\
\hline Konuralp Tip Dergisi & 27 \\
\hline Istanbul Hukuk Mecmuasi & 25 \\
\hline Turkish Thoracic Journal & 21 \\
\hline Journal of Critical Intensive Care & 19 \\
\hline Diagnostic And Interventional Radiology & 18 \\
\hline Eurasian Journal of Pulmonology & 18 \\
\hline European Review for Medical And Pharmacological Sciences & 18 \\
\hline International Journal of Mental Health and Addiction & 18 \\
\hline
\end{tabular}


Tablo 4. Yayınların Kurumlara Göre Dağılımları

\begin{tabular}{|l|l|}
\hline Kurum Adı & Yayın Sayısı \\
\hline Sağlık Bilimleri Üniversitesi & 305 \\
\hline Hacettepe Üniversitesi & 188 \\
\hline İstanbul Üniversitesi & 149 \\
\hline Ankara Üniversitesi & 121 \\
\hline İstanbul Üniversitesi Cerrahpaşa Tıp Fakültesi & 106 \\
\hline Gazi Üniversitesi & 103 \\
\hline Ankara Şehir Hastanesi & 94 \\
\hline Koç Üniversitesi & 72 \\
\hline İstanbul Medeniyet Üniversitesi & 71 \\
\hline Ege Üniversitesi & 70 \\
\hline Sakarya Üniversitesi & 68 \\
\hline Yıldırım Beyazıt Üniversitesi & 67 \\
\hline Marmara Üniversitesi & 65 \\
\hline T.C Sağlık Bakanlığı & 65 \\
\hline Ondokuz Mayıs Üniversitesi & 62 \\
\hline
\end{tabular}

Tablo 4 incelendiğinde ilk sırada 305 yayın sayısı ile Sağlık Bilimleri Üniversitesi yer alırken bunu Hacettepe Üniversitesi ve İstanbul Üniversitesi takip etmektedir.

Tablo 5'te çalışmaların yayın diline göre dağılımı verilmiştir.

Tablo 5. Yayınların Yayın Diline Göre Dağılımı

\begin{tabular}{|l|l|}
\hline Yayın Dili & Yayın Sayısı \\
\hline İngilizce & 2543 \\
\hline Türkçe & 141 \\
\hline Almanca & 2 \\
\hline İspanyolca & 2 \\
\hline Fransızca & 1 \\
\hline
\end{tabular}

Covid-19 konusu ile ilintili çalışmaların 2543'ü $(\% 94,75)$ İngilizce yayınlanmıştır. Sonraki en çok tercih edilen dil Türkçe olup, Almanca ve İspanyolca 2, Fransızca 1 adet yayına rastlanmıştır.

Belirtilen dönem için Covid-19 ile ilgili yayınların hangi alanlarda çalışan yazarlar tarafından gerçekleştirildiği ele alınan önemli hususlardan biridir. Şekil 1 'de yayınların araştırma alanlarına göre dağılımları sunulmuştur.

Şekil 1 incelendiğinde çalışmaları yayınlanan yazarların özellikle iç hastalıkları, psikiyatri, farmakoloji, dermatoloji alanlarında çalıştıkları anlaşılmaktadır.

Şekil 1. Yayınların Araştırma Alanlarına Göre Dağılımları

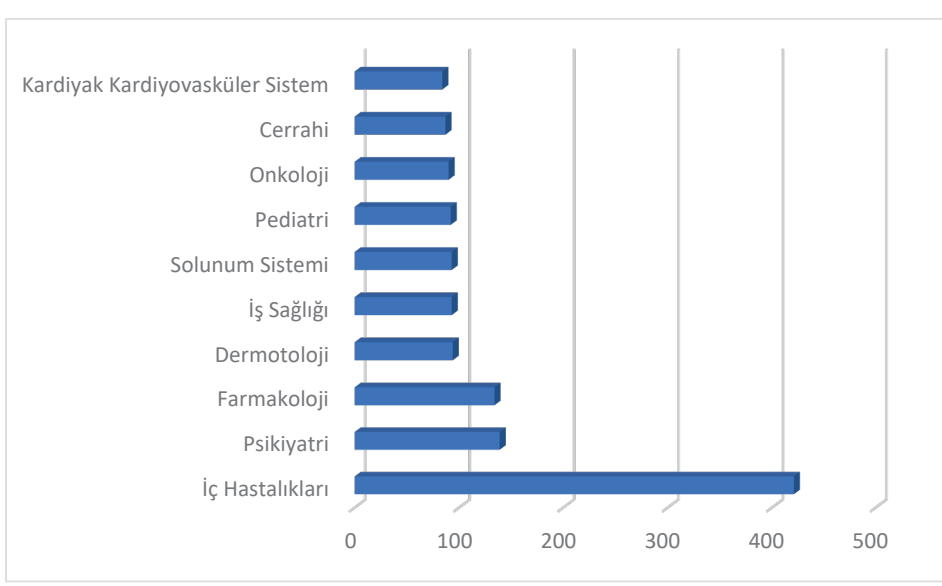




\subsection{Sosyal Ă̆ Analizi}

Covid-19 ile birlikte tüm dünyayı etkileyen bir pandemi ile karşı karşıya kalınmıştır. İlk aşamalarda Covid-19 hakkında bilgi eksikliği ve belirsizlik, sürecin anlaşılıp hızlıca hastalık yayılmadan gerekli önlemlerin alınması için yapılan çalışmaların sonuçlarının paylaşılmasını gerekli kılarken; yeni bulgulara ulaşmak, yorumlamak ve bu doğrultuda hızlı kararlar alıp süreci yönetmek adına ülkeler arası iş birliğinin önemini de beraberinde getirmiştir.

Bu çalışmada da bu iş birliği yapısını ortaya koymak adına öncelikle yazarlar, sonrasında ise ülkeler ve kurumlar arasındaki birliktelikler Sosyal A $\breve{g}$ Analizi yardımıyla analiz edilmiştir. Öncelikle yazarlar arasındaki iş birliğinin ortaya çıkarılması amacıyla SAA ile yazarlar arası ağ yapısı çizdirilerek Şekil 2'de gösterilmiştir.
Yazarlar arasındaki ağ yapısı incelendiğinde, gevşek bir ağ yapısı olduğu görülmektedir. Yazarlar arasındaki küçük gruplar arasında iş birlikleri söz konusu olup, sıkı bir iletişim ağı gözlenememiştir. En fazla adı geçen yazarlar Murat Yıldırım, Erkan Cure, Oğuz Karabay'dir.

Şekil 3'te yayınların ülkeler arası ağ yapısı ortaya konmuştur. Şekilde dairelerin büyüklüğü o ülkenin adının daha fazla geçtiğini, daireler arasındaki çizgi ise birlikteliğin olduğuna işaret etmektedir.

Ülkeler arası ağ yapısı incelendiğinde Türkiye'nin iş birliği içerisinde olduğu ülkeler olarak ABD, İngiltere ve İtalya ön plana çımakla birlikte, Türkiye'nin pek çok farklı ülkeler ile de iş birliği içinde olduğu da görülmektedir.

Şekil 2. Covid-19 Araştırmalarında Türkiye Kaynaklı Yayınlarda Yazarlar Arası Ağ Yapısı

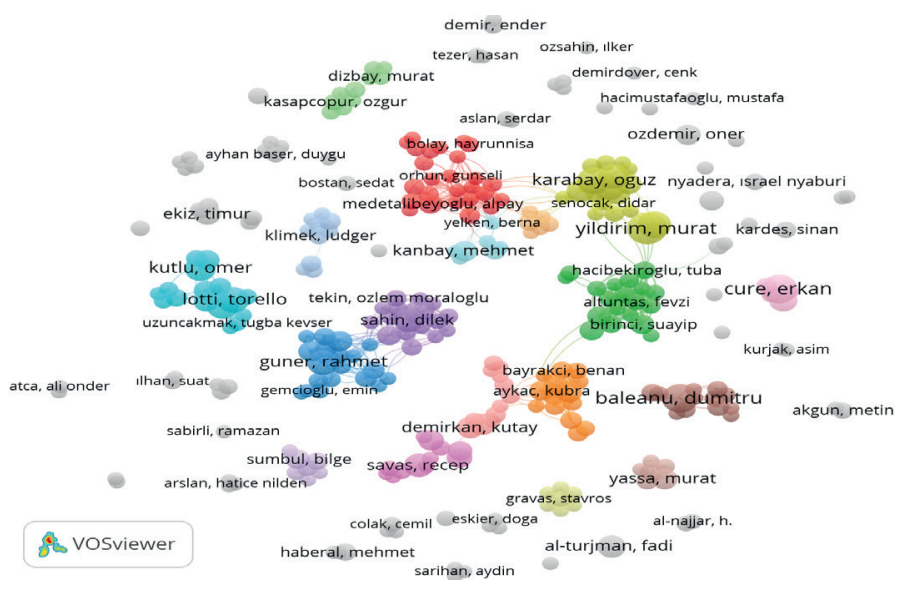

Şekil 3. Covid-19 Araştırmalarında Türkiye Kaynaklı Yayınların Ülkeler Arası A ̆̆ Yapısı

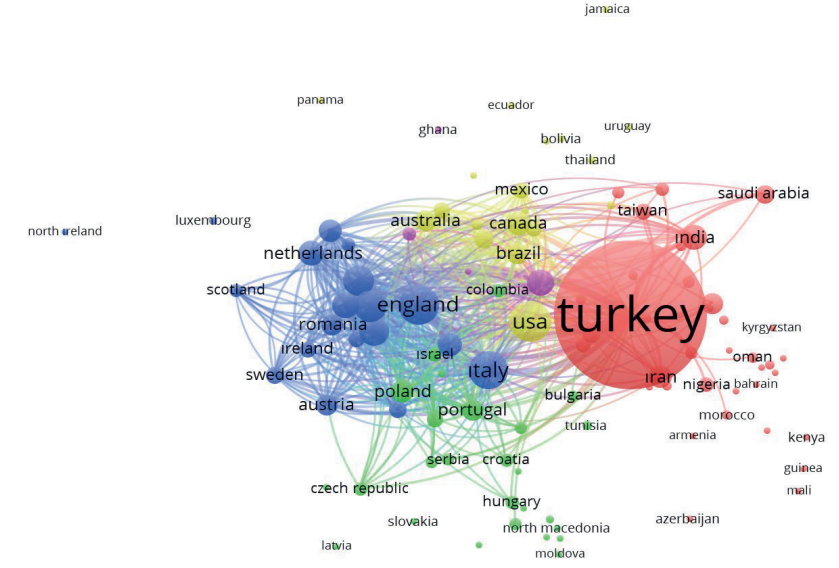

in vosviewer 
Birlikte çalışan yazarların kurumlar arası ağ yapısı Şekil 4'te verilmiştir.

Kurumlar arası ağ yapısı incelendiğinden ağ yapısının çok sıkı olmadığ görülmektedir. Hacettepe Üniversitesi, İstanbul Üniversitesi, Ankara Üniversitesi, Gazi Üniversitesi ve Koç Üniversitesi iletişim ağında öne çıkan üniversitelerdir. Koç Üniversitesi Türkiye'deki kurumlarla yapmış olduğu iş birliğinin yanı sıra diğer ülkelerdeki kurumlarla birlikte de çalışmalara imza atmıştır.

Pandemi sürecinde Covid-19 ile alakalı yapılan yayınlarında eğilimlerini takip edip araştırabilmek için öncelikli olarak anahtar kelimeler analiz edilmiştir. Sonrasında ise daha ayrıntılı bilgi edinmek amacıyla özetler incelenmiştir. Şekil 5'te yayınlardaki anahtar kelimeler arasındaki ağ yapısı gösterilmiştir.

Yayınlarda beklenildiği üzere anahtar kelime olarak en çok Covid-19 teriminin kullanıldığı görülmüştür. $\mathrm{Bu}$ terimi pregnancy, outbreak, pneumonia, respi- ratory failure, epidemology, telemedicine, personal protective equipment, treatment, healthcare workers, mental health kelimeleri takip etmektedir. Fiziksel sağlıkla ilintili olan bu terimlere ek olarak, psikolojik sağl1k ile ilintili anxiety, life satisfaction, loneliness, well being, covid-19 fear gibi terimlerinde yoğunlukla kullanıldığı görülmüştür.

Araştırma kapsamında yayınların özetleri incelenerek özetlerde en çok geçen kelimeler ve bunlar arasındaki birliktelikler de incelenmiş, elde edilen sonuçlar Şekil 6'da gösterilmiştir. Şekil 6 incelendiğinde görülebileceği gibi cov, fever, laboratory, participant, crisis terimleri sıklıkla tekrarlanan kelimeler olarak belirlenmiştir.

Cytokine storm, sars, inhibitor, drug, enzyme, angiotensin, pathogenesis protein, mutation kelimeleri covid ile birlikte sıklıkla kullanılan kelimelerdir. Bu kısım sağlık alanında yapılan çalışmalarda hangi alanlara yoğunlaşıldığına işaret etmektedir. Labora-

Şekil 4. Covid-19 Araştırmalarında Türkiye Kaynaklı Yayınların Kurumlar Arası Ağ Yapısı

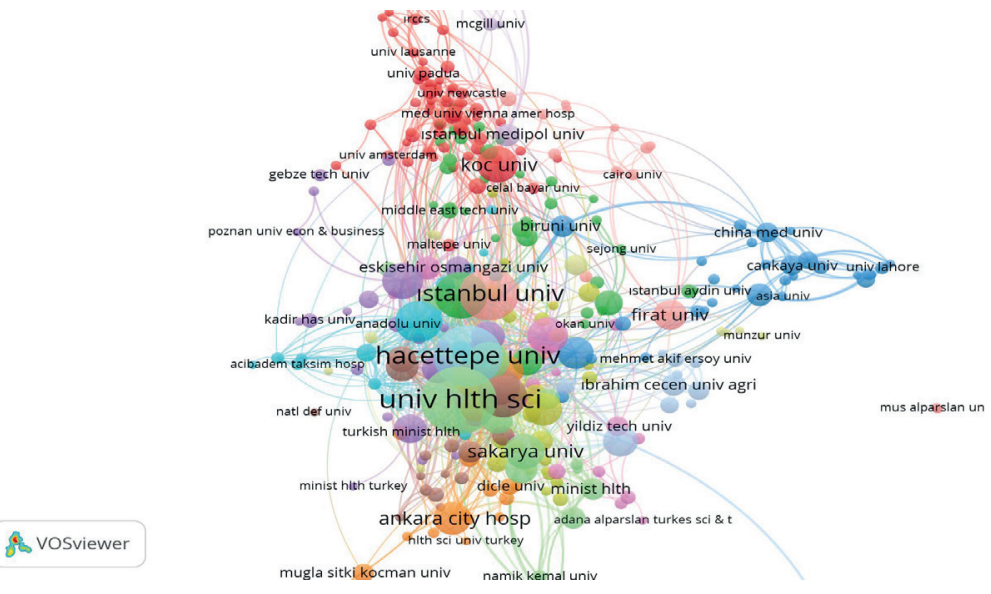

Şekil 5. Covid-19 Araştırmalarında Türkiye Kaynaklı Yayınların Anahtar Kelimelerinin Analizi

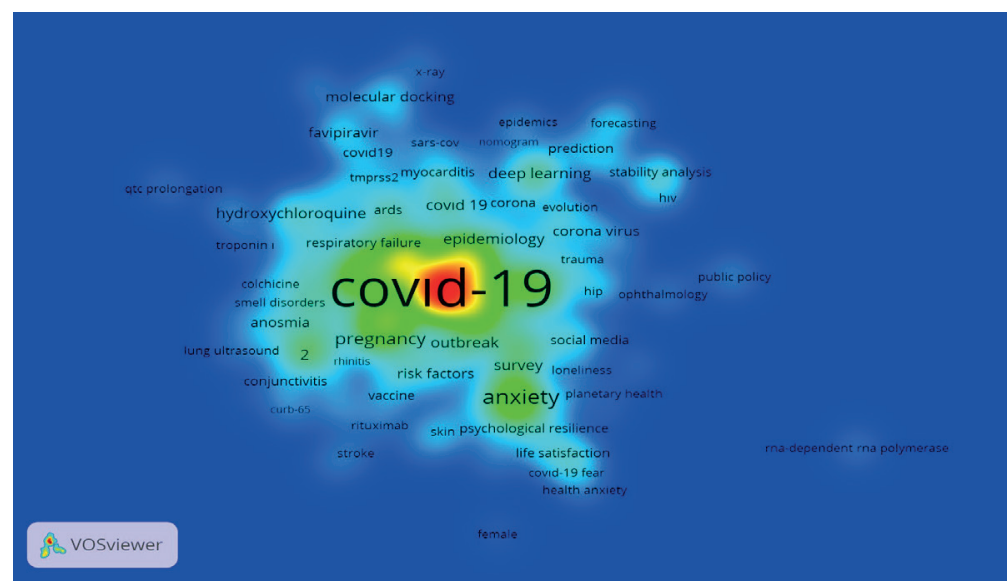


Şekil 6. Covid-19 Araştırmalarında Türkiye Kaynaklı Yayınların Özetlerinde Kullanılan Kelimeler

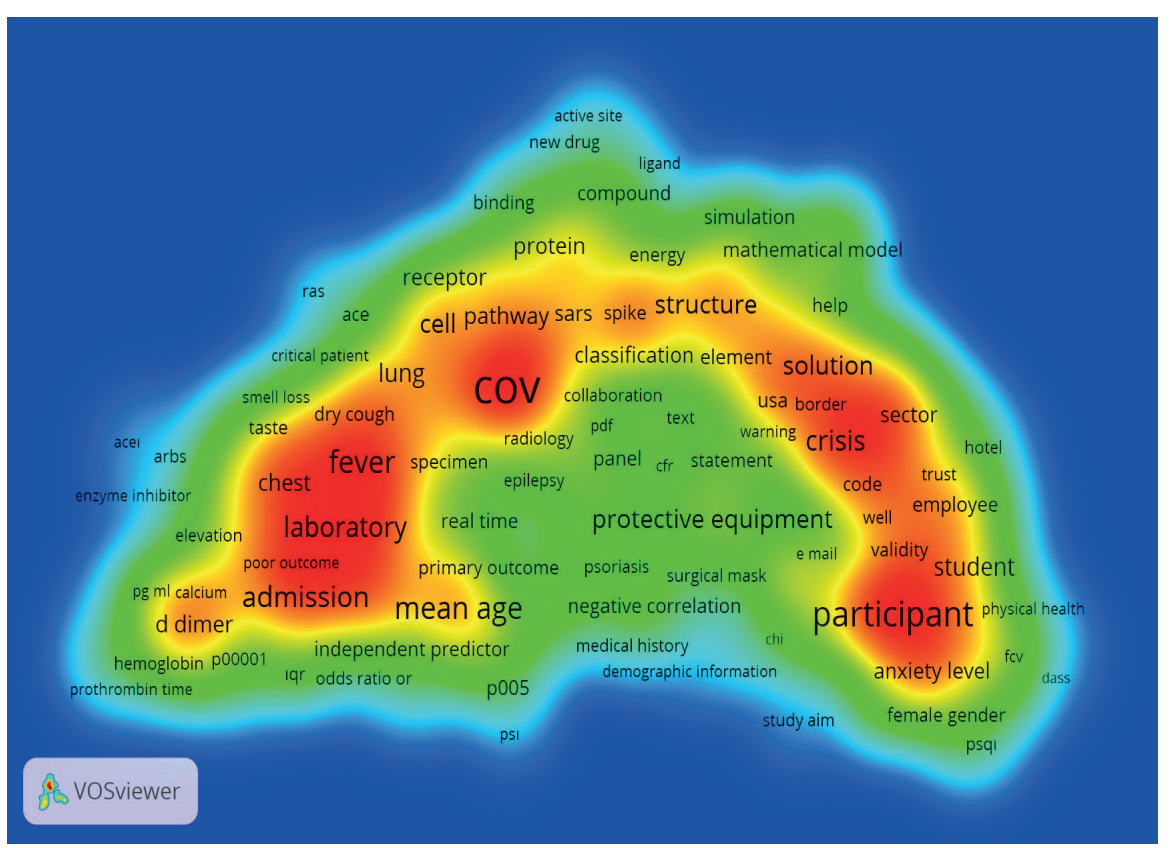

tory kelimesi ise en fazla intensive care unit, hospitality stay, prognosis, c reactive protein, serum, mechanical ventilation, vitamin $\mathrm{d}$, d dimer, hemoglobin, hospital mortality rate kelimeleriyle birlikte kullanılmıştır. Bu laboratuvar bulgu sonuçlarının incelenerek Covid-19 nedeniyle kişilerin hastanede kalma süresi ve ölüm oranları ile ilgili çalışmaların olduğuna işaret etmektedir. Bu kelimelerin sıklıkla geçtiği çalışmalarda kullanılan analiz türleri ve veri setlerinin de yapılan çalışmaların özetlerinde belirtildiği görülmüş ve incelenmiştir. İnceleme sonucunda veri setleri ve kullanılan analizler olarak logistic regression analysis, multivariate logistic regression, odds ratio, laboratory data bulunmuştur.

Anxiety, fear, mental health, attitude, sleep quality, Pittsburgh Sleep Quality Index, stress level, worry, life satisfaction, perceived stress scale, psychiatric disorder kelimeleri participant kelimesiyle birlikte siklıkla kullanılmıştır. Bu kelime birliktelikleri bir arada değerlendirildiğinde Covid-19 ile birlikte insanlarda meydana gelen kaygı, korku, uykusuzluk, salgının insanların psikolojisi üzerindeki etkilerinin ve yansımalarının regresyon analizi, korelasyon analizi ile araştırıldığı çalışmaların olduğunu göstermektedir.

Crisis kelimesi ile birlikte en fazla government, policy, industry, global, solution, business, tourism kelimeleri bir arada kullanılmıştır. Bu da yapılan çalışmaların bir kısmının pandemi süreci ile birlikte çeşitli sektörlerde ve iş dünyasında yaşanan krizleri, alınan devlet politikaları ve önlemleri ile ilgili konulara ağırlık verdiğini göstermektedir.

\section{SONUÇ VE ÖNERILER}

Bu çalışma kapsamında, 2020-2021 yılları arasında yayınlanan Covid-19 araştırmalarında Türkiye kaynaklı yayınların yıl bazındaki sıklık, yayın türü, yayınlandığ1 dergi, amaç, yöntem, araştırmacıların çalışma alanları bazında incelenmiştir. Ayrıca pandemi sürecinin getirmiş olduğu bilinmezlik ve belirsizlik sürecinde, elde edilen bulguların incelenmesi, analiz edilmesi ve değerlendirilmesi sürecinde yapılan iş birliklerinin önemli olabileceği düşüncesinden hareketle yazarlar, kurumlar, ülkeler arasındaki iş birliği SAA ile incelenmiştir. Çalışmada anahtar kelimeler ve özetler de incelenerek belirlenen alan üzerinde yoğunlaşılan ana konular ve analiz teknikleri belirlenmiştir.

Yapılan analiz sonucunda, yazarlar arasındaki küçük gruplar içinde iş birliklerinin olduğu söylenebilmektedir. Yazarlar arasındaki iş birliğinin devam etmesi, pandemi sürecinde elde edilen bulguların paylaşılması ve bunların incelenmesi, gerekli düzenlemelerin yapılmasında kaynak teşkil etmesi açısından önemlidir. İlerleyen dönemlerde küçük gruplar halinde bulunan bu iş birlikleri arasında ağların genişlemesinin yapılacak çalışmalara olumlu katkılar sağlayacağı düşünülmektedir.

Ülkeler arası iş birlikleri ağ yapısı incelendiğinde, Türkiye'nin pek çok farklı ülke ile iş birliği içinde 
olduğu görülmüştür. Kurumlar arasındaki ağ yapısı analiz edildiğinde, kurumlar arası iş birliklerinin ön plana çıktığı ve kurumların daha fazla köprü rolü oynadığı saptanmıştır. Kurumlar arası iş birliklerinin arttırılmasının ve çalışmaların daha geniş coğrafyalara yayılmasının çalışmalara birçok açıdan katkı sağlayacağı öngörülmektedir.

Hangi alanlarda çalışmaların sıklıkla yapıldığı, kullanılan veri setleri ve analiz yöntemlerini saptamak ve ilerde konu hakkında çalışma yapacak araştırmacılara fikir sağlamak adına yayınların özetleri de incelenmiştir. İnceleme sonucunda fiziksel sağlık alanıyla ilintili birçok terimin yoğunlukla kullanıldığı görülmekle birlikte sadece tek bir alanda değil psikoloji ve ekonomi gibi pek çok farklı alanda da pandeminin etkilerinin analiz edildiği belirlenmiștir. Covid-19'un insanların günlük yaşamlarında, davranışlarında büyük değişikliklere sebep olması yapılan çalışmalarda salgının insan psikolojisi üzerindeki etkisinin de incelenmesini beraberinde getirmiştir. Yapılan yayınlarda psikoloji ile ilintili kelimelerin sıkça kullanılması bunun bir işaretidir. Sonuç olarak, Covid-19 araştırmalarında Türkiye kaynaklı yayınlarda sağlık başta olmak üzere pek çok farklı alanda konunun ele alındığı saptanmıştır. Bundan sonra yapılacak olan çalışmalarda özetlerin içeriklerinin farklı tekniklerle analiz edilerek incelenmesi araştırma alanındaki en güncel gelişmelerin yakından takip edilmesinde ve yapılacak olan çalışmalara fikir verip yön vermesinde etkili olacaktır.
T.C SAĞLIK BAKANLIĞI (2020). Covid-19 Sözlüğü [çevrimiçi]. https:// covid19.saglik.gov.tr/TR-66494/pandemi.html [Erişim Tarihi: 9/06/2021].

VOSviewer, https://www.vosviewer.com/

YILDIRIM, İ.E. \& ERGÜT, Ö. (2006). Uluslararası Ekonometri. Yöneylem Araştırması ve İstatistik Sempozyumu'nun Bibliyometrik Analizi. Sosyal Bilimler Metinleri. Özel Sayı, 1-7.

Web Of Science [çevrimiçi], http://www.webofknowledge.com

\section{KAYNAKÇA}

BUDAK, F. \& KORKMAZ, Ş. (2020). COVID-19 Pandemi Sürecine Yönelik Genel Bir Değerlendirme: Türkiye Örneği. Sosyal Araştırmalar ve Yönetim Dergisi. 1, 62-79.

DSÖ (2021). WHO Coronavirus (COVID-19) Dashboard [çevrimiçi]. https://covid19.who.int/ [Erişim Tarihi: 11/06/2021].

DSÖ (2021). Timeline: WHO's COVID-19 response [çevrimiçi]. https:// www.who.int/emergencies/diseases/novel-coronavirus-2019/interactive-timeline\# [Erişim Tarihi: 11/06/2021].

PRITCHARD, A. (1969). Statistical Bibliography or Bibliometrics. Journal of Documentation. 25, 348-349.

RACHERLA, P. \& HU, C. (2010). A social network perspective of tourism research collaborations. Annals of Tourism Research. 37 (4), 1012-1034.

SMALL, H. (1999). Visualizing Science By Citation Mapping. Journal of the American Society for Information Science. 50, 799-813.

T.C SAĞLIK BAKANLIĞI (2020). Covid-19 Bilgilendirme Platformu [çevrimiçi]. https://covid19.saglik.gov.tr/TR-66935/genel-koronavirus-tablosu.html [Erișim Tarihi: 11/06/2021]. 